\title{
Distribution Pattern of Aculops lycopersici (Massee) (Acari: Eriophyidae) in Tomato Leaf and Estimation Method for the Population Density on Leaf
}

\author{
Akira KAwaI ${ }^{*}$ and Mohd. Mainul HAQUE ${ }^{\dagger}$ \\ National Institute of Vegetables and Tea Science, National Agriculture and Bio-oriented Research \\ Organization, Ano, Mie 514-2392, Japan
}

(Received 24 March 2003; Accepted 25 December 2003)

\begin{abstract}
The distribution pattern of Aculops lycopersici (Massee) in a tomato leaf and method for estimating the density of the mite were examined. The distribution pattern of adults and nymphs was similar. About a half number of mite population infested leaflets and the other half petioles. Most of the mites infested the upper surface of the leaves. On petioles, the density of the mite was high at the posterior part. Mite numbers were large on leaflets near the stem. The percentage of the number of mite population on each part of the leaflet to the total number on whole leaf did not vary irrespective of the population density. On leaflets, the mite density was higher in the middle than periphery and also higher at the bottom than the top. However, the density became uniform in the leaflet when the density became high. From the distribution data obtained, a method for estimating the densities of mite population on whole leaf was proposed, i.e. mite numbers on the second and third leaflets and several parts of the petiole were counted.
\end{abstract}

Key words: Aculops lycopersici, distribution pattern, tomato, sampling method, leaf

\section{INTRODUCTION}

Aculops lycopersici (Massee) is an important pest of tomato Lycopersicon esculentum Mill. The injury first appears on the leaf and stem of tomato plants and in the case of high density of mite infestation also on the fruit (Bailey and Keifer, 1943). In leaves, the epidermal cells of the leaflet are destroyed, resulting in a curling of the leaflet edges, rusting of damaged tissue, desiccation, and plant death (Keifer et al.,1982; Royalty and Perring, 1988).

Haque and Kawai (2002) showed the distribution of A. lycopersici in tomato plants. More than $70 \%$ of the mite population infested leaves and the positions of the leaves with high population density of the mite moved upward. A. lycopersici infested both upper and lower surfaces (Royalty and Perring, 1988) but preferred the upper surface of tomato leaf (Royalty and Perring, 1996). It also preferred areas surrounded with veins in leaflets (Royalty and Perring, 1988). However, the distribution of A. lycopersici in tomato leaf has yet to be reported.

\footnotetext{
*Corresponding author

${ }^{\dagger}$ Present address: Department of Zoology, Rajshahi University, Rajshahi 6205, Bangladesh
} 
The present study was designed to examine the distribution of A. lycopersici in tomato leaf and to establish a method for estimating the population density on whole leaf.

\section{MATERIALS AND METHODS}

Tomato Plant and Infestation A. lycopersici was released onto ten potted tomato plants (cultiver 'House Momotaro') on May 24th, 2000. Infestation was achieved by attaching an infested leaflet to the eighth leaf from the bottom of each plant. The number of mites released was not counted. The mites used were collected in Mie Pref. in November 1999 and then cultured on potted tomato plants at $25 \pm 5^{\circ} \mathrm{C}$ in the laboratory of the National Institute of Vegetables and Tea Science (NIVTS).

Distribution in Leaf. Two and three weeks after the release, the distributions of adults and nymphs, respectively, were examined on three plants. The number of mites on the 8 th to the 17 th leaf from the bottom of each plant was counted. For each leaf, the mites on both surfaces of all leaflets were enumerated and the petiole was divided in three parts with same length and numbers of mites on each part were counted (Fig.1). The total number of adults and nymphs was more than 50 on 15 leaves out of 60 . The data for these 15 leaves were

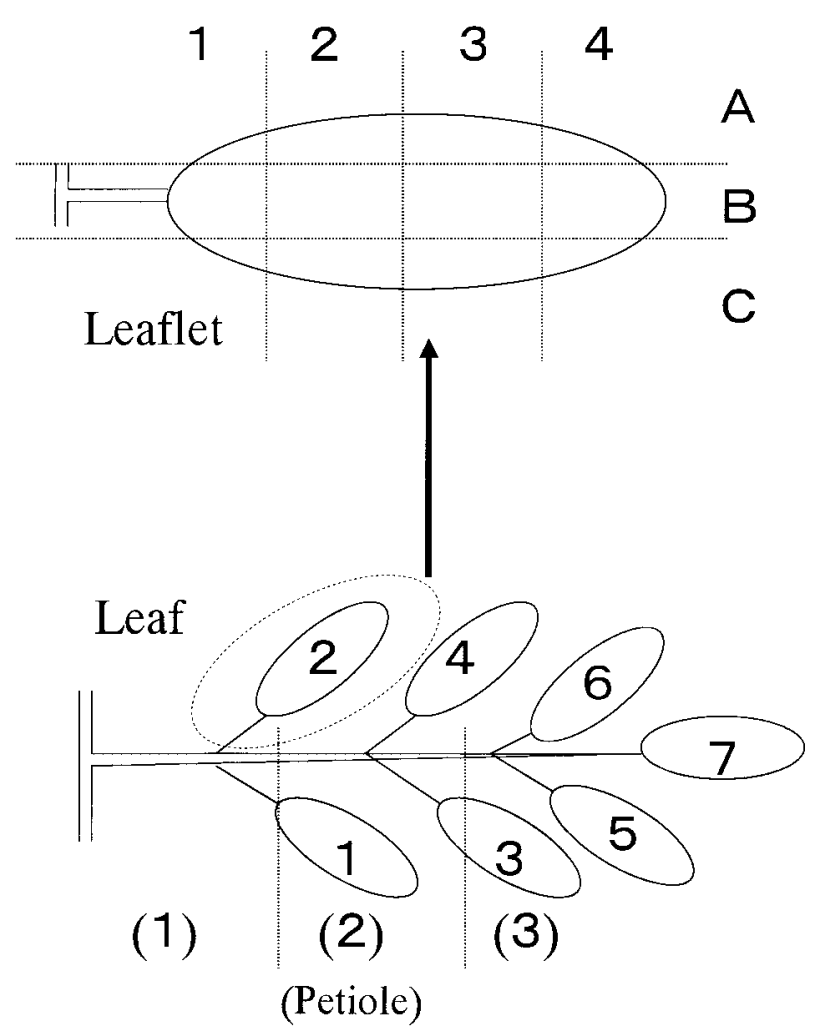

Fig. 1. Method of division of the leaf and leaflet for examination of the micro distribution of $A$. lycopersici in tomato leaves. 
used to examine the mite distribution.

Mite distribution in Leaflet. Three and four weeks after release, the distributions of adults and nymphs, respectively, were examined on leaflets. Each week, ten leaflets with high population densities of mites were removed from the plant. Each leaf was divided into 12 parts as shown in Fig.1. The adults and nymphs on the upper surface of each part were enumerated and the area of each part was measured using the leaf area meter.

\section{RESULTS}

Mite distribution in Leaf. Adults and nymphs of A. lycopersici infested both leaflets and petioles. About a half of all adults and nymphs were found on leaflets irrespective of the population density (Fig. 2). The percentage of adults and nymphs on leaflets averaged 52.3 and $58.0 \%$, respectively, but the deviation was large when the density was low.

The distribution of A. lycopersici on petioles is shown in Fig. 3. The density of both adults and nymphs is high at the posterior and low at the anterior part. The percentage of adults and nymphs infesting the posterior one third of the petiole was 64.5 and $66.5 \%$, respectively. That of adults and nymphs infesting the anterior one third was 7.7 and $6.7 \%$.

On leaflets, most adults and nymphs of $A$. lycopersici infest the upper surface. The percentage of adults on the lower surface was $10.5 \%$ while that of nymphs was only $2.0 \%$. The percentage of the total number of mite population on each of the seven leaflets is shown in Fig. 4. The rate for both adults and nymphs is high on the lower-most leaflets and low on the upper-most leaflets. This tendency was stronger in nymphs. Some 32.6-38.0\% of adults and $38.6-43.9 \%$ of nymphs were present on each of the first to second leaflet, $7.9-9.6 \%$ of adults and $12.8-14.0 \%$ of nymphs on each of the third to fourth leaflet and $0.3-1.3 \%$ of

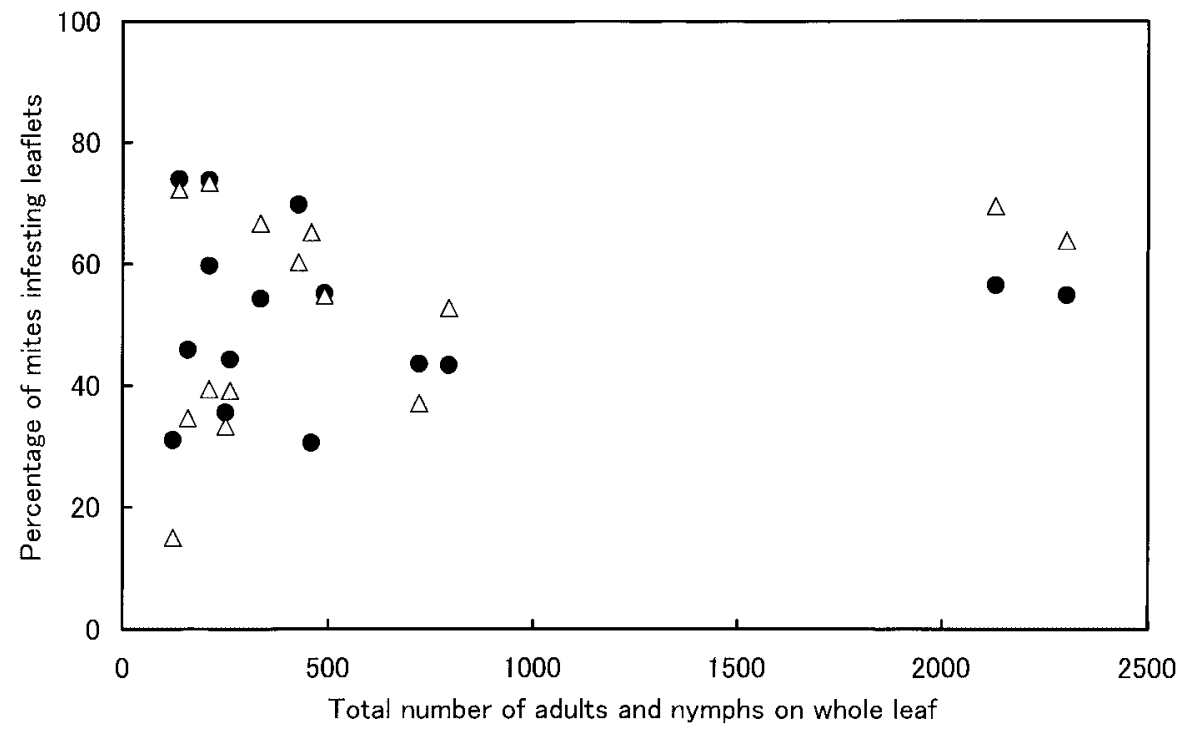

Fig. 2. Relationship between the number of A. lycopersici on whole tomato leaf and the percentage infesting leaflets. : adults, $\triangle$ : nymphs 


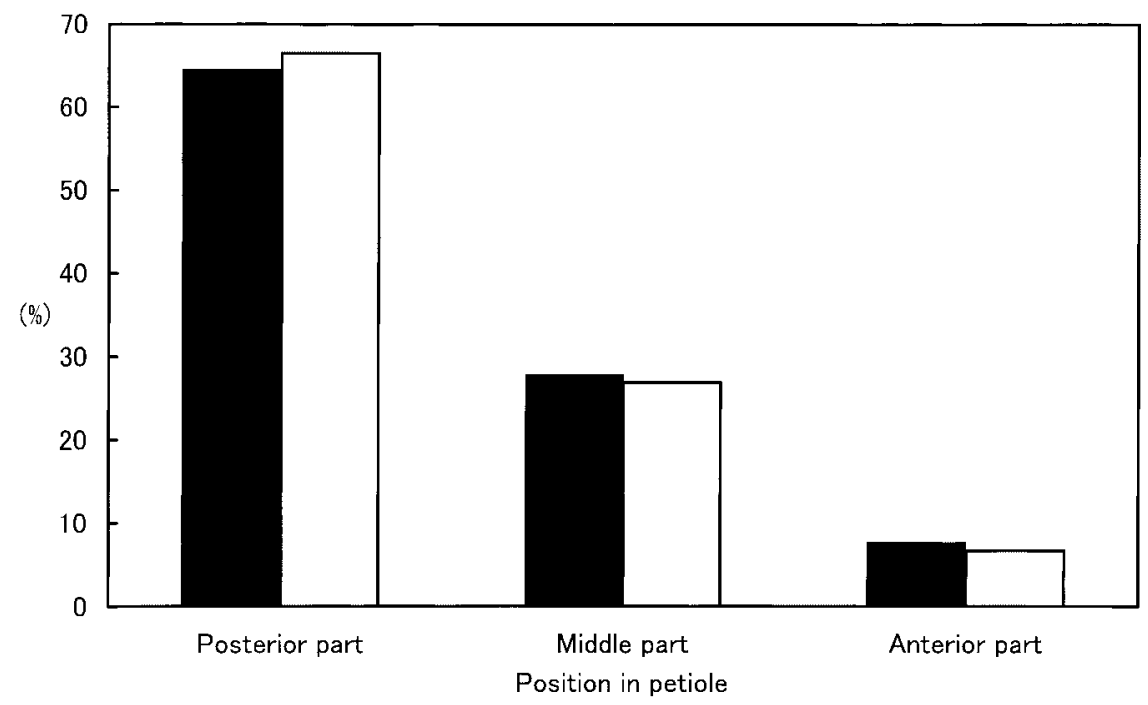

Fig. 3. Micro distribution of A. lycopersici in petiole of tomato leaf. See Fig. 1 for the position in the petiole. $\square$ : adults, $\square$ : nymphs

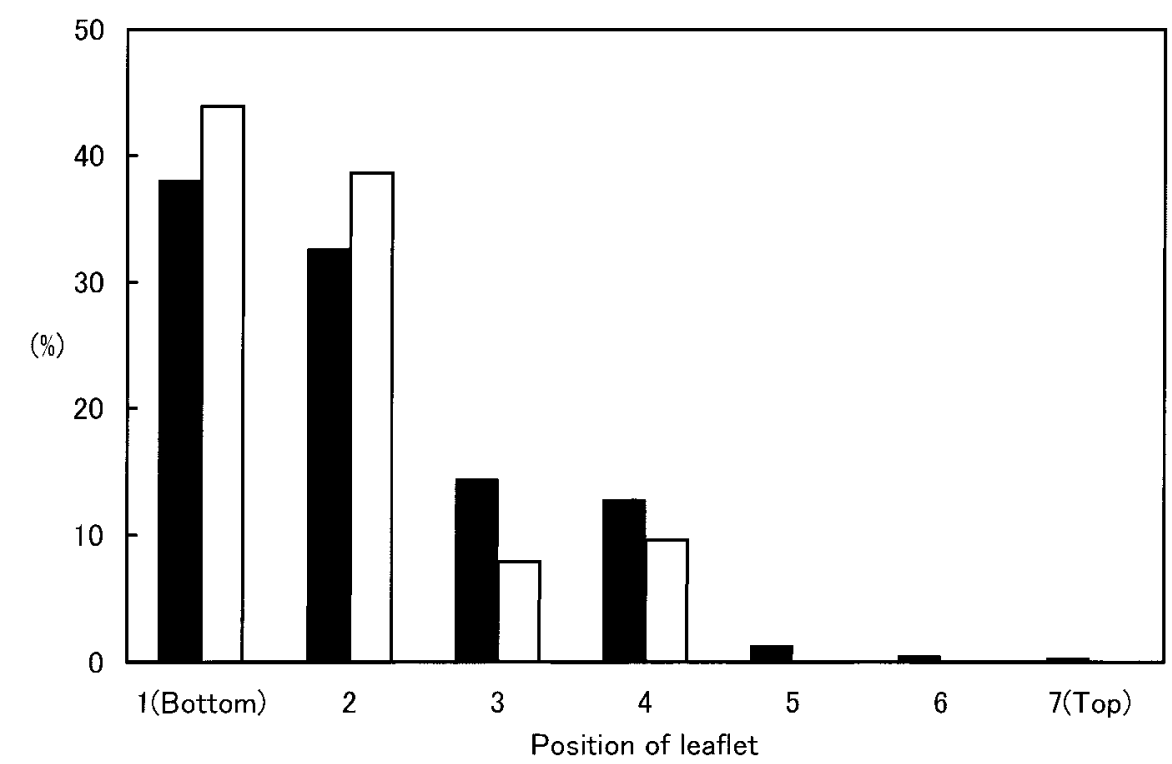

Fig. 4. Micro distribution of A. lycopersici between leaflets of tomato leaf. See Fig. 1 for the position of leaflets. $\square$ : adults, $\square$ : nymphs

adults and no nymphs on each of the fifth to seventh leaflet. Population density did not affect the percentages on each leaflet, and $47.0 \%$ of adults and $46.5 \%$ of nymphs were, in total, observed on the second and third leaflets (Fig. 5). When the population density was low, the deviation for nymphs was large while that for adults was small.

Mite distribution in Leaflet. The population densities of A. lycopersici on various parts of 


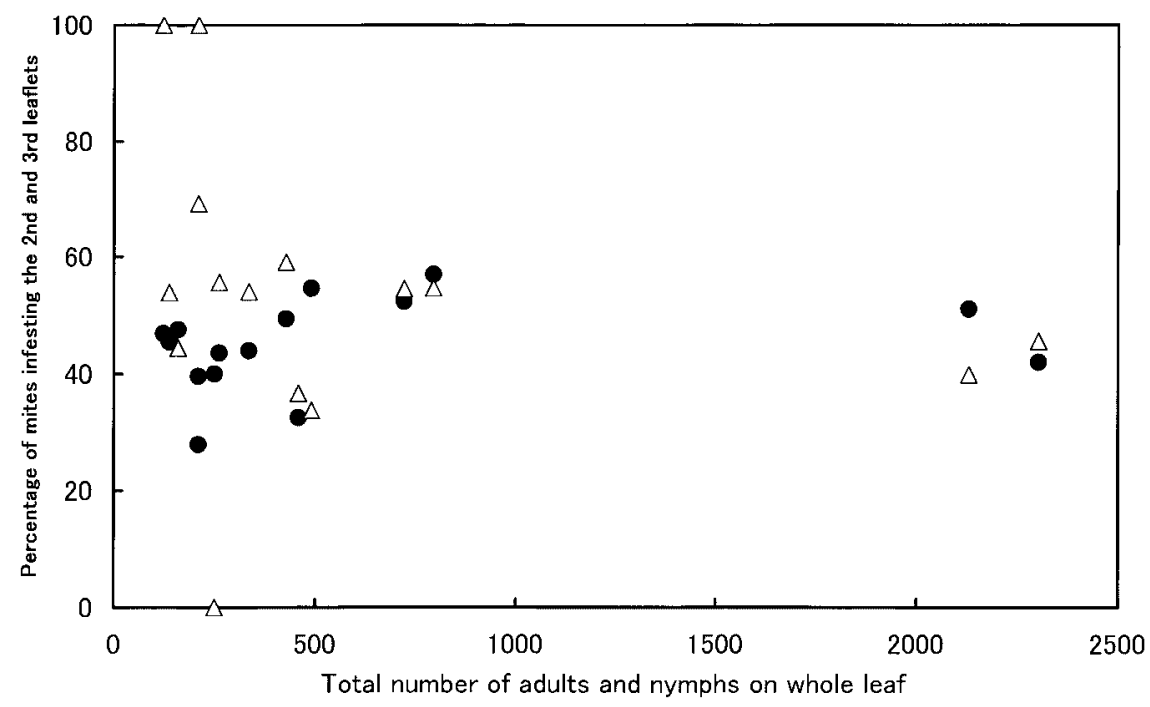

Fig. 5. Relationship between the number of adults and nymphs of $A$. lycopersici on whole tomato leaf and the percentage infesting the second and third leaflets. See Fig. 1 for the position of leaflets. : adults, $\triangle$ : nymphs

the leaflet are shown in Fig. 6. At three weeks after release, the densities of both adults and nymphs were significantly higher in the middle than peripheral parts and also significantly higher at the posterior than the anterior parts. However, at four weeks after release, there was no significant difference in the densities of either adults or nymphs among the parts of the leaflet.

The relationships between the distribution of $A$. lycopersici on leaflets and the densities of the mites are shown in Fig. 7. The percentage of both adults and nymphs that infested the middle or posterior part tended to decrease, as the density became higher. This tendency was clearer in nymphs than in adults.

\section{DISCUSSION}

Since A. lycopersici is minute, it is impossible to count with the naked eye and a binocular microscope is essential. Since the densities become very high (Haque and Kawai, 2002) and the leaves of a tomato plant are large, it is very difficult to count the whole number of mite population on a leaf and a sampling method should be applied. In order to determine the best sampling method, the distribution pattern of the mite on leaves and leaflets should be considered.

Haque and Kawai (2002) reported the distribution of adult A. lycopersici in the tomato plant. It infested both leaves and stem. The mite density differed with the position of the stem and leaf, and the leaf position and part of stem with the largest population moved upward with time. It is therefore necessary to take count of the mite densities on various parts of the stem and various leaves to estimate the total population density of a whole tomato plant.

In the tomato leaf, adults and nymphs of $A$. lycopersici infested both the leaflet and petiole 

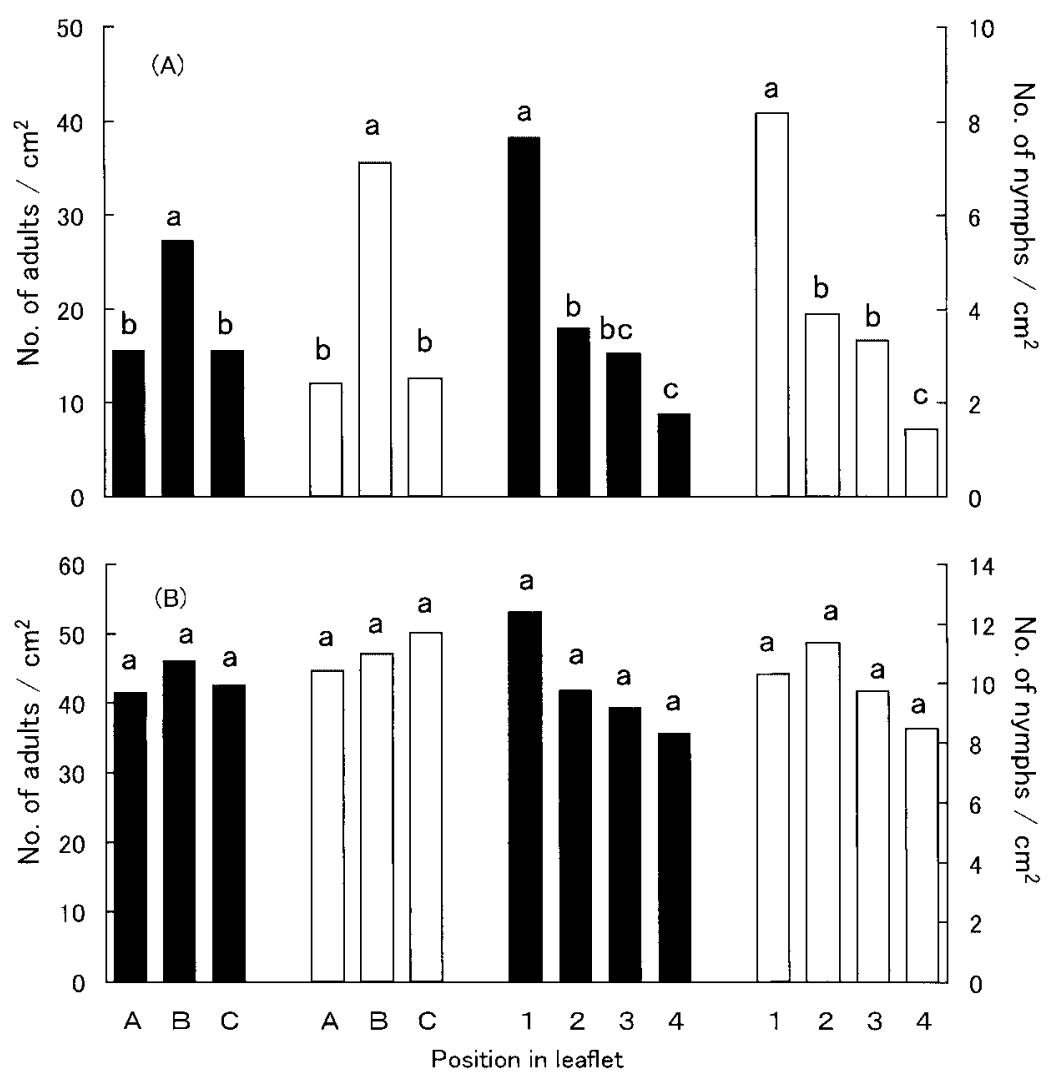

Fig. 6. Comparisons of the densities of adults and nymphs of $A$. lycopersici in various parts of tomato leaflet. See Fig. 1 for the position of leaflets. Bars with different letters are significantly different by Scheff's multiple comparison test $(P=0.05)$. (A) three weeks after release, (B) four weeks after release

and the percentage of the mite densities found on leaflets was about 50\% (Fig. 2). However, it is necessary to take count of the mite densities on both petioles and leaflets in order to estimate the total population density on a leaf since the deviation in the percentage was large when the population density was low. Since the density of both adults and nymphs on a petiole differs with position (Fig. 3), it is necessary to count mite individuals on several parts of the petiole to estimate the total population density on a petiole.

Most adults and nymphs of $A$. lycopersici infest the upper surface of leaves (Fig. 4). It was reported that $A$. lycopersici preferred the upper surface of tomato leaves (Royalty and Perring, 1996). The leaf surface preferred by Eriophyoid mites, however, differed with the mite species and host plants. Abacarus hystrix preferred the upper surface of Italian ryegrass leaves (Gibson, 1974), while Acaphylla theae (Radhakrishnan et al., 1987) and Acaphylla theavagrans (Kawai, 1995) preferred the lower surface of tea leaves. Preferences were stronger in nymphs than in adults (Fig. 4) and this tendency was also observed in A. theavagrans (Kawai, 1995). Since more than $85 \%$ of both adults and nymphs are found on the upper surface and it is difficult to count numbers on both surfaces, it is acceptable to count 


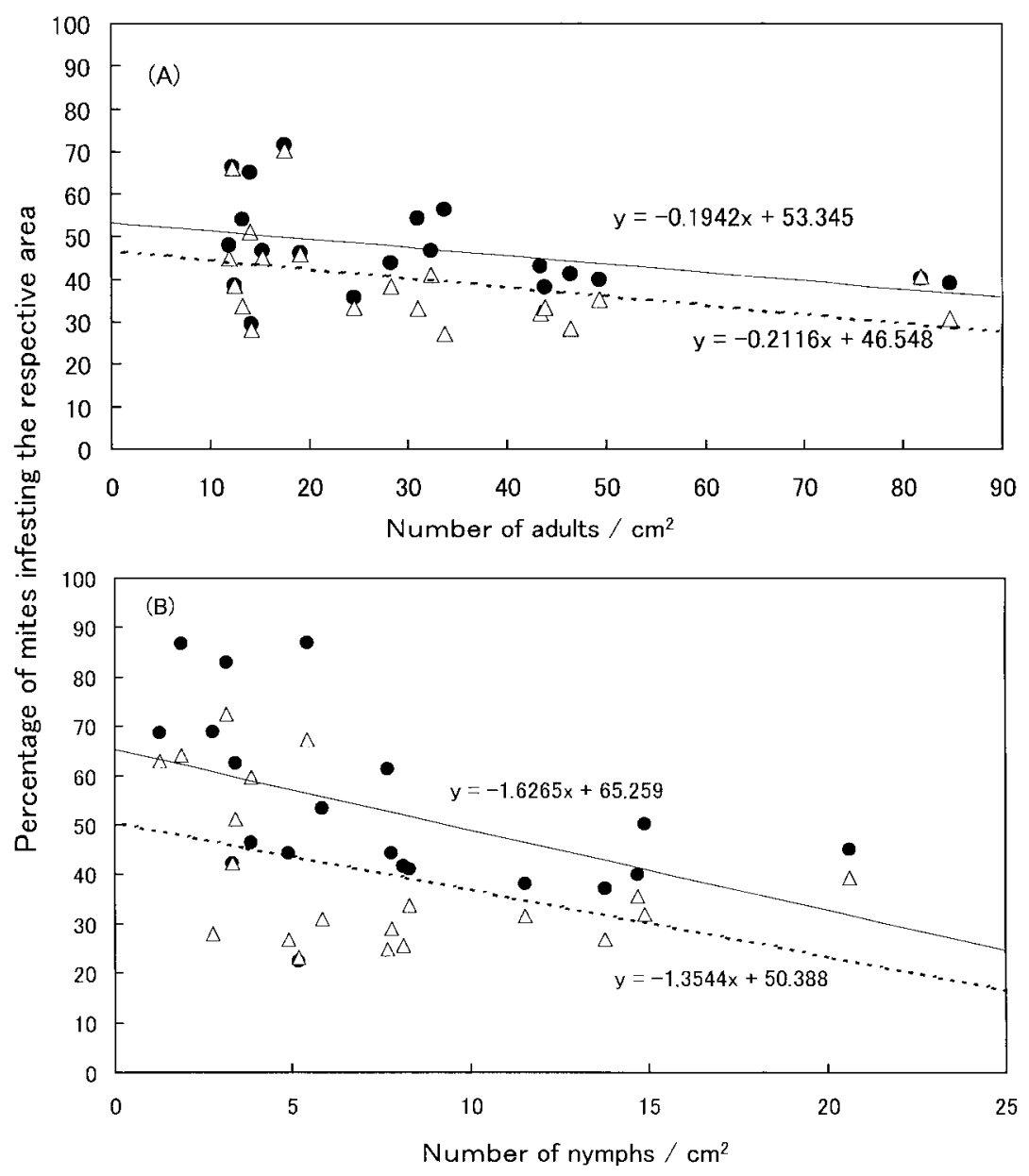

Fig. 7. Relationship between the number of A. lycopersici on whole tomato leaflet and the percentage infesting the middle and posterior parts. See Fig. 1 for the position of the parts. (A) adults, (B) nymphs, $\mathrm{O}$ : middle part (part B), $\triangle$ : posterior part (part 1)

the number on only the upper surface.

The number of both adults and nymphs of $A$. lycopersici differs with the position of the leaflet being larger for the leaflets at the bottom and smaller for those of the top of the plant (Fig. 5). Since this species invades new leaves by walking, it is more likely to reach the lower leaflet and so it reproduces there. Since the percentage of both adults and nymphs on the second and third leaflets relative to the total number of mite population on all leaflets was definite irrespective of the population density (Fig. 6), the total number can be estimated from the number on the second and third leaflets.

In tomato leaflets, the densities of both adults and nymphs were high near the midvein and also the base. This tendency was only clear when the population density was low (Fig. 7). Royalty and Perring (1988) stated that A. lycopersici first fed on the area surrounding veins and later migrated outward. Acaphylla theavagrans (Kawai, 1995) and Abacarus hystrix 
(Gibson, 1974) also preferred the parts around the midvein of tea and Italian ryegrass leaves, and $A$. hystrix preferred the base of Italian ryegrass leaves. When the density is low, $A$. lycopersici prefers to settle around the midvein of the base. However at high density, it is forced to disperse throughout the leaflet. Since the distribution pattern for a leaflet differs according to population density (Fig. 7), it is difficult to adopt a sampling method to estimate precisely the whole number of mite population on leaflets. However, for a simple estimation, it is appropriate to sample several leaf disks from a leaflet. In this case, disks should be cut from various parts of the leaflet.

From the distribution pattern of $A$. lycopersici on tomato leaves, we propose a sampling method for estimating the total population density on a leaf. The petiole is cut into several pieces, the length of each piece is measured and the number of the mite in a central region of
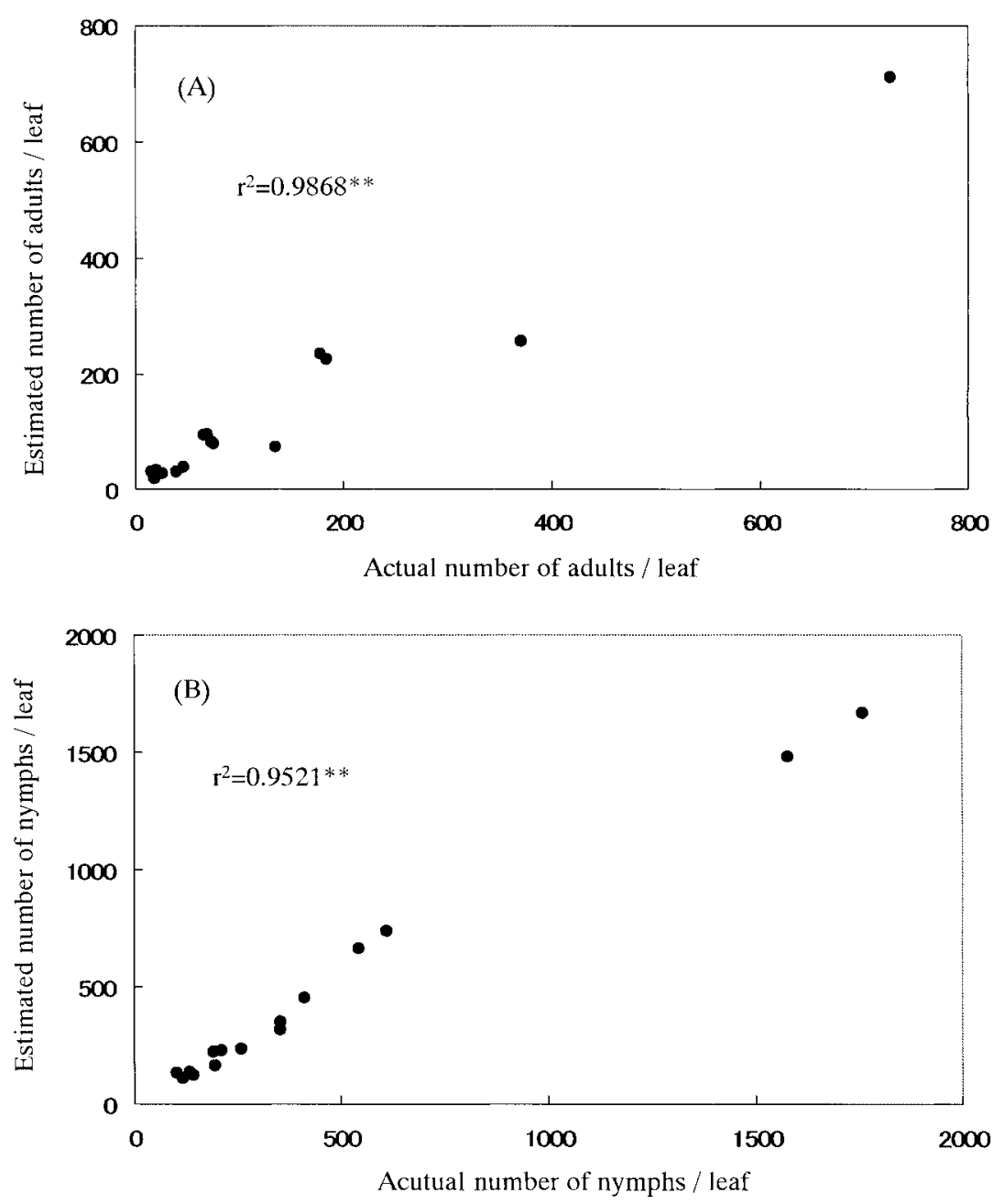

Fig. 8. Relationship between the actual and estimated number of $A$. lycopersici on whole tomato leaf. See Fig. 1 for the position of the parts. (A) adults, (B) nymphs 
$2 \mathrm{~cm}$ of each piece is counted. The numbers on the second and third leaflets are also counted. The total number of mite population for the entire leaf is estimated as

$$
\mathrm{N}_{\mathrm{t}}=\sum_{\mathrm{n}=1}^{\mathrm{k}}\left(\mathrm{N}_{\mathrm{n}} \times \mathrm{L}_{\mathrm{n}} / 2\right)+\left(\mathrm{N}_{\mathrm{L} 2}+\mathrm{N}_{\mathrm{L} 3}\right) / a
$$

where $\mathrm{N}_{t}$ is the total number of mite population on the leaf, $\mathrm{N}_{\mathrm{n}}$ is the number in the central region of each piece of petiole, $\mathrm{L}_{\mathrm{n}}$ is the length of each piece of petiole, $\mathrm{N}_{\mathrm{L} 2}$ and $\mathrm{N}_{\mathrm{L} 3}$ are the numbers on the second and third leaflets and $a$ is the percentage of mite number on the second and the third leaflets to the mite number on all leaflets ( 0.470 for adults and 0.465 for nymphs).

The relationships between the actual number of mites on whole leaf and the number of mites estimated by proposed equations are shown in Fig. 8. Since the strong correlation was observed between the actual and estimated number $\left(\mathrm{r}^{2}\right.$ for adult is 0.9521 and that for nymph is 0.9868 ), proposed equations would be useful for estimating the number of mite population on whole leaf.

\section{REFERENCES}

Bailey, S. F. and H. H. Keifer (1943) The tomato russet mite, Phylocoptes estructor Keifer: Its present status. Journal of Economic Entomology, 36: 706-712.

Gibson, R. W. (1974) Studies on the feeding behaviour of the eriophyid mite, Abacarus hystrix, a vector of grass viruses. Annals of Applied Biology, 78: 213-217.

Haque, M. M. and A. Kawai (2002) Population growth of tomato russet mite, Aculops lycopersici (Acari: Eriophyidae) and its injury effect on the growth of tomato plants. Journal of the Acarological Society of Japan, 11: 1-10.

Kawai, A. (1995) Distribution pattern of Acaphylla theavagrans Kadono and method of estimation of the population density. Bulletin of the National Research Institute of Vegetables, Ornamental Plants and Tea, B8: 23-31.

Keifer, H. H., E. W. Baker, T. Kono, M. Delfinado and W. E. Styler (1982) An illustrated guide to plant abnormalities caused by eriophyid mites in North America. USDA Agric. Handbook No. 573. 178pp.

Radhakrishnan. B., N. Muraleedharan, R. Selvasundaram and R. Varatharajan (1987) Seasonal abundance of Acaphylla theae (Watt), (Eriphyidae: Acarina) in a tea field at the Anamallais. Journal of Coffee Research, 17: 105-106.

Royalty, R. N. and T. M. Perring (1988) Morphological analysis of damage to tomato leaflets by tomato russet mite (Acari: Eriophyidae). Journal of Economic Entomology, 81: 816-820.

Royalty, R. N. and T. M. Perring (1996) Nature of damage and its assessment. In: Eriophyoid mites; their biology, natural enemies and control. (eds., Lindquist, E. E. and M. W. Sabelis), pp.493-512, Elsevier, Amsterdam.

\section{摘要}

トマトサビダニAculops lycopersici のトマトの葉内での分布と密度推定法

河合章・Mohd. Mainul Haque（野菜茶業研究所）

トマトサビダニの葉内分布を施設トマトで調べ，密度推定法を検討した．成虫と若虫の葉 内分布は同様であった. 約 $50 \%$ が小葉に, 約 $50 \%$ が葉柄に寄生して扣り, 小葉では大部分が 表面に寄生していた，葉柄では基部ほど密度が高く，基部に近い小葉ほど密度が高かった。 小葉内では中央部や基部で密度が高かったが, 全体の密度が高くなると分布は均一となった. 分布様式から，第 2 及び第 3 小葉と葉柄の数力所の個体数を調査することにより，葉全体の 密度を推定する方法を提案した。 